\title{
Sobre $O$ direito à preguiça de Paul Lafargue
}

\author{
Suzana Guerra Albornoz \\ Departamento de Ciências Humanas da Universidade de Santa Cruz do Sul (UNISC)
}

\begin{abstract}
O texto analisa o manifesto $O$ direito à preguiça (1880), de Paul Lafargue, no qual se expõem questões de atualidade em nosso tempo, quando a automação da produção pelas novas tecnologias diminui a necessidade material de trabalho e cria uma situação mundial inquietante. A crítica da ideologia do trabalho contida no discurso de Lafargue sugere o questionamento da moderna tábua de valores que toma o trabalho como valor maior. Este ensaio termina por reconsiderar, segundo as tradições clássicas do humanismo, e mesmo da tradição religiosa, a diminuição do trabalho e o ócio como possibilidades de desenvolvimento humano - da contemplação, do espírito, do pensamento, da cultura, da saúde -, desafiando os educadores para novas atitudes.
\end{abstract}

Palavras-chave: Lafargue, Trabalho, Preguiça, Ócio, Superprodução, Desemprego, Educação.

\section{On The right of laziness of Paul Lafargue}

The text presents the manifest The right of laziness (1880), of Paul Lafargue, where are shown problems still of our time, when the automation of production through new technology lesses the material need of work and creates a disturbing world situation. The criticism contained in the speech of Lafargue, before the work ideology, suggests the discussion of the modern table of moral values organized around the leading value of work. This essay finishes by considering, according of the classical traditions of humanism, even of religious tradition, the lessing of work and laziness as possibilities for human development - by contemplation, spiritual activity, culture, health -, designing new challenges for educators.

Keywords: Lafargue, Work, Laziness, Leisure, Overproduction, Unemployment, Education.

Y piensan unos que no habría miséria si todos trabajaran. Piensan bien. Pero podrían pensar mejor. La suma de trabajo supera las necesidades de la espécie (Vigil, 1959, p. 13).

\section{Introdução}

C sta pretende ser a parte final da pesquisa intitulada Trabalho e utopia na modernidade - de CThomas More a Paul Lafargue, que venho desenvolvendo com o apoio da Universidade de Santa Cruz do Sul. Este texto dá continuação, portanto, a quatro ensaios anteriores (Albornoz, 2003, 2005, 2006a, 2007), respectivamente sobre Thomas More, Tommaso Campanella, Jean-Jacques Rousseau e Charles Fourier, todos publicados nos Cadernos de Psicologia Social do Trabalho.

Há uma quase inevitabilidade de abordar o manifesto de Paul Lafargue (1842-1911) numa pesquisa com o intuito de fazer aparecer o elo entre as idéias sobre o trabalho e a literatura de caráter utópico dos tempos modernos.

Ao pesquisar as relações tecidas entre a utopia social, a experiência prática e o pensamento interpretativo do trabalho durante os séculos que constituem o que se convencionou chamar de modernidade, chega-se à crítica do trabalho tal como se dá no mundo capitalista da tecnologia industrial que, como Max Weber apontaria no início do século XX, está intimamente ligado à moral protestante, justificadora e estimulante das dinâmicas da economia burguesa. 
Ao atravessar a crítica do mundo moral e social da revolução industrial no início do século XIX, quando se ultrapassa a gigantesca performance teórico-prática de Karl Marx e Friedrich Engels desenvolvida ao longo daquele século, é-se levado ao encontro daquele pequeno manifesto publicado como O direito à preguiça (1880) por Paul Lafargue ${ }^{1}$.

Opúsculo sem pretensão propriamente científica nem rigor filosófico, contudo extraordinário pela grande expressividade retórica e admirável acerto econômico, que de certo modo é também ético, apesar de que nele possam ser detectados alguns excessos de expressão, em relevância política $O$ direito à preguiça só pode ser comparado ao Manifesto comunista.

A consideração de um texto como esse, situado ao mesmo tempo no plano literário da retórica e no centro do embate social, das idéias referentes à economia política, apela fortemente para a questão ainda hoje não bem resolvida das relações entre filosofia, ciências humanas e a prática histórica.

E porque estão de momento como que postos em quarentena os postulados da teoria crítica, um texto de retórica política como o que aqui consideramos pode talvez parecer menos relevante, tanto para a filosofia como para as ciências sociais contemporâneas que, na reflexão teórico-crítica formavam um amplo caminho aberto e concertado de uma única ciência social onde as contribuições da sociologia, da antropologia, do marxismo, da psicanálise, da psicologia social e da economia podiam combinar-se com as dos ensinamentos dos grandes filósofos clássicos gregos, dos iluministas e idealistas de várias procedências, e com as imaginações fecundas dos utopistas.

O pequeno e famoso escrito de Lafargue lembra-nos que, se não é prudente julgarmos o valor de um texto por sua inserção ou não no paradigma filosófico-científico da moda, também não é lícito julgá-lo por seu tamanho, pois, sob muitos pontos de vista, tanto o literário-expressivo e o da força de persuasão, como os da acuidade científico-econômica e da qualidade utópica, no sentido de perspectiva de futuro e antecipação de problemas extremamente atuais mais de um século após sua publicação, as poucas páginas de $\mathrm{O}$ direito à preguiça superam em relevância milhares de produções auto-intituladas filosóficas ou científicas, que constituem a realidade acadêmica de nosso tempo.

Socialista de origem latino-americana e presença francesa, importante líder do movimento operário europeu, co-fundador do Partido Socialista Francês, ${ }^{2}$ o nome de Lafargue não só não consta dos dicionários de filósofos, como também não se encontra naqueles que fazem o inventário das utopias, embora o seu famoso ensaio-panfleto seja animado de forte impulso antecipador e transformador, carregado daquele germe de real que ainda não se realizou, soando ainda hoje como provocador quando recomenda a jornada de três horas para todo cidadão.

Por vários motivos, parece-me razoável situá-lo entre os autores da grande tradição das utopias, das utopias concretas que movem a história e impulsionam o novo, segundo a reconceituação e revaloração procedidas por Ernst Bloch, que já tive ocasião de apresentar ${ }^{3}$.

Essa deve ser a constatação dos leitores mais atentos do manifesto de Lafargue, pois é a posição expressa pelo apresentador da primeira tradução brasileira, que considera a obra herdeira da tradição do gênero das utopias, ao utilizar o paradoxo e a sátira para expressar a

\footnotetext{
1 Na edição organizada por Domenico De mais (2001), numa re-interpretação, o texto é publicado como O direito ao ócio, denominação que teria sido pensada pelo autor, antes de decidir-se pelo título $O$ direito à preguiça.

2 Para dados biográficos de Lafargue, ver as apresentações das edições de seus livros listadas ao final do artigo. Marilena Chaui sugere, para estudos mais pormenorizados, o trabalho de L. Derfler: Paul Lafargue and the founding of french marxism, 1842-1882, Harvard University Press, 1991; do mesmo autor e editora: Paul Lafargue and the flourishing of french socialism, 1998.

3 Em Ética e utopia (Albornoz, 2006b), O enigma da esperança (Albornoz, 1999) e Violência ou não-violência (Albornoz, 2002). A obra-prima de Ernst Bloch, O princípio esperança, foi recentemente traduzida para o Brasil pela Editora Contraponto (2006).
} 
crítica social e a proposta de uma outra realidade, julgando haver Lafargue retomado considerações do socialismo utópico enquanto suas fontes remontam aos pensadores clássicos da Antigüidade (Hardman, 1980, p. 18).

A atualidade desse inspirado manifesto manteve-se intacta no século que passou e é a mesma em nosso tempo de tão radicais mudanças tecnológicas que afetam os modos de vida, de produção, consumo e comunicação, bem como os modos de interpretação do real e de seus sentidos.

As observações de Lafargue e os apelos críticos de seu manifesto soam muito fortes e verdadeiros ainda para os nossos dias, quando o espectro do desemprego ronda o espírito da população jovem mesmo nas regiões mais desenvolvidas ou industrializadas do planeta, talvez mesmo, ainda mais nelas que nas outras, conforme quer-nos indicar a atual sociologia do trabalho.

O direito à preguiça nas últimas décadas vem sendo publicado em traduções no Brasil e aqui recebeu apresentações de importantes intelectuais a que recorreremos como introdução ao nosso tema.

\section{As apresentações de Lafargue para o Brasil}

A primeira tradução brasileira de O direito à preguiça veio a acontecer em 1980, cem anos após sua publicação na França. Deve ter contribuído para esse atraso a dificuldade para a circulação das idéias de esquerda durante a ditadura militar, sobretudo entre 1968 (quando Lafargue conheceu um renascimento de sua obra na França e em outros países) e 1979, quando o Brasil começou a superar a censura da expressão de idéias com a anistia política.

O nome de Lafargue, no entanto, não era desconhecido do movimento operário brasileiro no início do século XX e os historiadores interpretam que só a extrema burocratização da vida sindical brasileira, ocorrida após 1930, pode fazer entender o longo eclipse de seu nome entre nós (Hardman, 1980, p. 10).

De 1980 para cá, vêm sendo entregues ao público brasileiro algumas traduções e reedições, acompanhadas de introduções ou prefácios assinados por intelectuais de renome. Assim, além da apresentação da primeira tradução, de Francisco Food Hardman, contamos com as apresentações das professoras de filosofia Marilena Chaui e Olgária Matos, e também dispomos em português da introdução feita por Domenico De Masi, sociólogo italiano bastante conhecido em nosso país.

Antes, pois, de considerarmos diretamente o texto que é nosso objeto neste ensaio, com o objetivo de nos inserirmos na rede coletiva do debate, julgamos interessante relembrar o conteúdo das apresentações mencionadas.

Em sua apresentação de 1999, Marilena Chaui estabelece relação entre o discurso de Paul Lafargue e as teses de Max Weber em Ética protestante e espírito do capitalismo, que tanto marcaram a sociologia no século XX (Chaui, 1999, pp. 12-13).

Não se deve esquecer que Lafargue escreve em 1880, enquanto o famoso trabalho de Weber é publicado mais tarde (pela primeira vez, em 1904, mas em sua forma completa recém em 1920), o que dá ao discurso de Lafargue uma nota a mais de originalidade e antecipação.

A relação entre economia e religião encontrava-se na análise marxista, sendo que, no contexto do determinismo econômico, ao "ópio do povo" era atribuída a dependência das relações materiais de trabalho e de classe, ou seja, a religião adquiria a significação de 
ideologia, daquele discurso que tende a justificar, falseando, as submissões próprias da inserção nas tramas sociais da produção.

$\mathrm{Na}$ interpretação weberiana do mesmo problema (e Marilena Chaui interpreta que Weber escreve contrapondo-se a Marx), fica evidente a valoração oposta, pendendo a balança para o outro lado, aparecendo a religião, no caso o protestantismo, o luteranismo e ainda mais o calvinismo, como pólo influente na mesma ligação reconhecida entre economia e religião, enquanto pela doutrina da predestinação e a ética da salvação pelo trabalho, e pela proibição do ócio e do luxo que lhes é associada, ao mesmo tempo em que se estimula a disciplina, a atividade sem descanso e a poupança, é favorecida a acumulação capitalista e o desenvolvimento da economia burguesa.

Evidentemente, as análises de Weber (2004) não são fáceis de compreender nem se devem simplificar, sendo bem clara a observação que termina a obra, quando o escritor alerta:

embora o homem moderno geralmente não seja capaz de imaginar o efetivo alcance da significação que os conteúdos de consciência religiosa tiveram para a conduta de vida, a cultura e o caráter de um povo, não cabe contudo, evidentemente, a intenção de substituir uma interpretação causal unilateralmente "materialista" da cultura e da história por uma outra espiritualista, também ela unilateral (p. 167).

No tempo entre Marx e Weber situa-se Lafargue, que publicou em 1909 um ensaio sobre o determinismo econômico na concepção marxista (Lafargue, 1909), tendo sido muito ligado à luta concreta operária socialista bem como ao destino pessoal de Marx, de quem era genro, organizando, com a colaboração de Laura Lafargue, sua mulher, a publicação do célebre Do socialismo utópico ao socialismo científico (Engels, 1988). O interesse nessa publicação já aponta para a preocupação do organizador que, ao tempo em que se mantém socialista revolucionário e na fidelidade à interpretação marxista da história, quando valoriza as razões econômicas, também abre janelas para a ação política não determinada, para a liberdade, expressando-se como um humanista sensível às dimensões humanas que se situam além da economia e do trabalho.

Marilena Chaui ressalta, de outro lado, o gênero retórico em que se escreve o manifesto, aspecto da obra que reputa como ao mesmo tempo significativo e esquecido, por razões compreensíveis ligadas ao intuito de destacar o conteúdo essencial do texto, mas que merece ser mais considerado do que o foi nas análises anteriores (Chaui, 1999, pp. 30-31).

É de observação comum o quanto nosso tempo desconfia da retórica, como se a arte do discurso significasse imediatamente abandono da aspiração à verdade, quando nela se trata de usar de maior arte, do artifício expressivo, quando a finalidade é caprichar na forma até a veemência, para transmitir melhor o pensamento que se quer levar ao leitor, ou ao ouvinte, para conquistá-lo à mesma convicção, intenção legítima e própria das melhores causas e conquistas da cultura.

O "enigma" da servidão voluntária que aparece no texto de Lafargue como espanto ante a paixão do trabalho desenvolvida pela classe operária, esta que se torna patente na reivindicação pelos operários do direito ao trabalho, provoca a comparação com La Boétie em seu Discurso da servidão voluntária, no século XVI (Chaui, 1999, pp. 27-30).

Para Lafargue, quem se deixa explorar na cadeia de montagem industrial, como para La Boétie quem dá o poder ao tirano, são os súditos, os humilhados e ofendidos, os oprimidos, os operários, justamente pela sua submissão.

Se os operários não se deixassem explorar, se os súditos não se deixassem mandar, as situações poderiam tornar-se mais de acordo com os melhores sonhos humanos e não teríamos tanta espoliação da força de trabalho nas engrenagens da indústria, assim como se tem diminuído o poder autocrático nas democracias modernas; é claro, não sem conflito e 
contínua tensão com a tendência ao retorno à tirania e à barbárie que, o século XX viu bem, não desaparecem definitivamente.

Para que não se interprete o texto de Lafargue como apenas uma utópica apologia do ócio, Marilena recupera o conceito positivo, hegeliano-marxista do trabalho, que julga ser a motivação mais profunda e permanece sob a crítica de Lafargue ao trabalho alienado na sociedade industrial capitalista, buscando, nessa recuperação conceitual, apoio nas análises de Herbert Marcuse em Razão e revolução (Chaui, 1999, p. 33).

Ainda que se aceite a interpretação de haver um tanto de ironia, própria da arte retórica, no discurso de Lafargue, que se manteria marxista em sua valorização do trabalho como meio de sobrevivência e reconhecimento e, portanto, pela afirmação da dignidade do sujeito trabalhador e cidadão, não há como negar uma clara força de verdade nas frases sonoras em que ele critica a religião do trabalho e a paixão pela atividade na rede profissional e produtiva, onde aparece a proposta de revalorização do ócio.

Onde a classe trabalhadora teria esquecido que ser plenamente humano significa algo mais que produzir? Quando os trabalhadores abandonaram seu gosto e respeito pelo jogo, a diversão, a dança, a festa, o descanso, as horas do recolhimento, o ritual, o convívio com os amigos, a família, o encontro amoroso, a reunião da comunidade, a associação, o partido? Quando houve a conversão geral ao trabalho profissional em detrimento da vida liberta dos cuidados menores da sobrevivência?

Os antigos e os medievais teriam levado mais a sério que os modernos essas dimensões da existência humana para além do trabalho, que enobrecem pelo menos tanto quanto a atividade útil.

Nesse sentido da revisão do valor do trabalho ante o restante da experiência da vida, Paul Lafargue procede a uma trans-valoração, retomando a antiga tábua de valores em que se prezava o ócio, fazendo mesmo a preguiça aparecer como virtude, no sentido de virtù, como força, como energia (Chaui, 1999, pp. 44-45).

Lafargue considerava com esperança o progresso técnico, tão evidente e que tanto fazia sonhar na belle époque, ou seja, na última quadra do século XIX, no começo do XX. Pensava a máquina como potência libertadora, como condição material (potencial) de libertar os escravos do trabalho alienado e do domínio do capital (Chaui, 1999, pp. 46-47).

Todavia, acentua Chaui, "o sonho acabou", no sentido de que foram frustradas as esperanças de libertação dos trabalhadores através da técnica e da tecnologia (pp. 47-49).

Após as grandes desilusões do século XX, dilacerado entre as duas grandes guerras européias que se tornaram mundiais; tendo vivenciado o mundo dividido pelo confronto ideológico que se convencionou chamar de Guerra Fria; quando, no entanto, a tecnologia progrediu, às vezes no sentido da destruição, outras de modo mais criativo e inovador, apareceu a todos, muito nítida, a separação entre o progresso científico, técnico ou tecnológico, e a paz e felicidade social, ou desenvolvimento humano.

A liberdade dos trabalhadores assalariados e em geral dos indivíduos contemporâneos jogados nas novas situações do capitalismo tardio pródigo em invenção tecnológica, mesmo e especialmente após a simbólica "queda do muro de Berlim", é questionada e revista pelos sociólogos e filósofos críticos.

As análises de Marcuse, em Eros e civilização como em $O$ homem unidimensional, são algumas das críticas mais contundentes dos efeitos de manipulação e controle exercidos nas situações sociais da tecnologia avançada, a que a autora se remete (Chaui, 1999, p. 47).

Marilena Chaui termina a apresentação de $O$ direito à preguiça referindo-se às observações mais recentes sobre os nexos do trabalho e do "tempo livre" desenvolvidas por Viviane Forrester (1997), que procede à análise dos caminhos mais controladores que 
libertários da indústria cultural, assim como da indústria do lazer, do esporte e do turismo no capitalismo contemporâneo (Chaui, 1999, pp. 50-56).

Em sua apresentação de 2001, Domenico De Masi também sublinha a visão positiva de Paul Lafargue sobre o poder emancipatório das máquinas, com a que o sociólogo se identifica, pois efetivamente os maquinismos podem, ou melhor, poderiam ser usados como oportunidade de superação da escravidão do trabalho alienado (De Masi, 2001, p. 36).

Como vimos na breve recuperação dos comentários de Marilena Chaui, entre as posições atuais não predominam as esperanças no poder libertador do avanço tecnológico; a literatura crítica do trabalho no capitalismo tardio sabe salientar as armadilhas, as metamorfoses da dominação que se escondem no progresso tecnológico.

Contudo, olhando sem preconceito os diversos lados da questão, podem-se perceber as possibilidades contraditórias, como que as duas faces do mesmo fenômeno, que faz com que a mesma tecnologia que dá condições a novas formas mascaradas, sorrateiras de servidão e dominação, também abra oportunidades concretas para a libertação do trabalhador, ou melhor, para a libertação do trabalho e a emancipação pelo trabalho.

A dificuldade que se prende a essa possibilidade de liberação, não acreditada nem bem aceita, tem a ver com outra série de problemas mal-resolvidos no plano da organização social, da distribuição dos meios de sobrevivência, de renda, produção e consumo, bem como especialmente no da ideologia e das concepções filosóficas e religiosas, sobre o sentido da vida e da existência humana.

O polêmico sociólogo italiano ressalta as análises sociológicas de Lafargue, que caracterizava a sociedade da época em sua divisão: de um lado, os operários, tomados pela "paixão funesta" do trabalho; de outro, os capitalistas, condenados, pela má distribuição do trabalho, ao ócio forçado, à improdutividade e ao superconsumo; entre eles, os serviçais subalternos, encarregados do cuidado do desperdício vistoso dos ricos; e ainda, finalmente, aqueles únicos indivíduos que têm "amor pelo trabalho", que são os pequeno-burgueses no campo, os agricultores, e os pequeno-burgueses na cidade, os comerciantes em suas lojas.

A crítica de Lafargue é de que o proletariado, que poderia se rebelar e, em rebelandose, mudar a sociedade, em vez disso sucumbiu ao "vício" do trabalho alienado (De Masi, 2001, pp. 30-31).

De Masi insiste em que Lafargue estabelece nítida associação entre supertrabalho e superconsumo, e em como essas observações ainda são apropriadas para as realidades cada vez mais globais do novo capitalismo de nosso tempo.

Após cem anos da publicação do manifesto de Paul Lafargue, a única vitória do proletariado, imerso em sua ideologia do trabalho, teria sido estender à burguesia a loucura de matar-se de supertrabalho e intoxicar-se com superconsumo, excitados uns e outros por necessidades fictícias criadas pela propaganda (De Masi, 2001, p. 32).

Sendo assim, as sugestões de limitação do trabalho e desenvolvimento do ócio implicam em necessidades de profunda transformação humana, sobretudo de ordem psicológica, afetiva e mental, imaginária e ideológica, ética e moral, ou seja, de dimensão imaterial.

Essa transformação está posta como tarefa para os educadores, e este é ponto importante a que desejamos voltar mais adiante, quando reconsideraremos também a posição de De Masi sobre as exigências educacionais das novas realidades.

Em seu prefácio à tradução de $O$ direito à preguiça de 2003, Olgária Matos começa por acentuar que Paul Lafargue foi um pioneiro, quando observou que libertar o trabalhador, o proletário, não significa fazer desaparecer o capital ou os capitalistas, mas permitir ao operário livrar-se "de sua alma”, que é o princípio de sua própria sujeição (Matos, 2003, p. 8). 
Do mesmo modo que Marilena Chaui, a autora associa o discurso de Lafargue, em um movimento de oposição e complementação, às teses de Max Weber, bem como ao Discurso da servidão voluntária de La Boétie. Como um La Boétie moderno, que no século XVI redigiu seu Discurso da servidão voluntária, no qual defendia que ser livre e desejar a liberdade são o mesmo, Lafargue considerava que ser livre seria não desejar a tirania do trabalho (Matos, 2003, p. 9).

O texto acentua a revolução valorativa central produzida por Lafargue, que encontrou inspiração nas tradições antigas clássicas, grega e romana - que prezavam, mais que o labor e ainda mais que a arte, a skholé e o otium (p. 12).

O lugar da skholé (palavra grega que se encontra, como se nota facilmente, na raiz da palavra "escola", o que já dá o que pensar) é uma questão que se torna um desafio, que provoca a ordem das idéias e dos princípios morais, e transforma-se em grande tarefa prática, a começar por uma revisão de conceitos e novas formas de operar aos agentes do mundo educacional contemporâneo.

O direito à preguiça seria a forma originária de uma teoria crítica da sociedade moderna. Não veicula diretamente reivindicações econômicas ou políticas, mas nasce da necessidade de uma vida diversa, liberada da tirania do mercado e do Estado capitalista, ou seja, acrescentaríamos, tal como era próprio do pensamento autenticamente utópico do século XIX.

Consiste na antecipação da teoria crítica sobre a mais contemporânea das realidades, enquanto critica a ética da produção e do consumo, do cotidiano e da lógica do mercado, da indústria, da ciência e da técnica, em suas conseqüências desumanas, recusa a moral tecnocrática e a economia subtraída ao controle humano.

Segundo a professora Matos, Paul Lafargue teria encontrado uma posteridade em Guy Debord, autor de A sociedade do espetáculo, e nos situacionistas a ele ligados, sendo o situacionismo um dos movimentos político-culturais mais importantes de nosso tempo.

\section{O pequeno grande texto: excertos comentados}

Ponto de partida do veemente manifesto é a constatação da mania que se apossou da classe operária nos tempos modernos, obsessão doida porque se trata justamente de loucura pelo trabalho que, na situação da sociedade industrial capitalista, é alienado em seus aspectos e dimensões humanizantes, conforme já haviam demonstrado as análises marxistas.

Lafargue (2003) detecta a estranha paixão pelo trabalho mesmo este sendo aviltante e a denuncia, pois, como insana obsessão pelo que avilta, o que é para entendermos em parte como linguagem retórica, na clave da ironia, mas também consiste em crítica real à tábua de valores que tem o trabalho no cume:

Uma estranha loucura dominou as classes operárias das nações onde reina a civilização capitalista. Essa loucura traz como conseqüência misérias individuais e sociais que há séculos torturam a triste humanidade. Essa loucura é o amor ao trabalho, a paixão moribunda que absorve as forças vitais do indivíduo e de sua prole até o esgotamento (p. 19).

Os males do trabalho submetem e maltratam as multidões do tempo industrial, sem que os sujeitos tomem consciência do que os oprime. Lafargue constata que a realidade da sociedade ocidental burguesa no capitalismo do final do século XIX carrega a contradição de, 
por um lado, prometer e esperar o bem-estar, a riqueza, o reconhecimento social através do trabalho e, de outro, só reservar sofrimento e miséria para as massas trabalhadoras. "A nossa época é, dizem, o século do trabalho; na verdade, é o século da dor, da miséria e da corrupção" ( Lafargue, 2003, p. 29).

A modernidade havia posto grande expectativa sobre a libertação do excesso de esforço corporal pelas novas máquinas, bem como sobre a superação das submissões próprias dos regimes de servidão e escravidão, pela passagem ao trabalho assalariado nas novas situações de trabalho urbanas e coletivas, nas manufaturas e fábricas. Os reformadores sociais utópicos que antecederam Lafargue, até a segunda metade do século XIX, apostavam no poder libertador do trabalho assalariado.

As análises da sociologia marxista, embora mudando o paradigma, observações críticas e conclusões, continuavam a apostar no poder libertador do trabalho, esperando e dando por cientificamente assentado que a classe trabalhadora fosse o sujeito detentor do poder transformador da sociedade, porque capaz de conhecer a sociedade desde o ponto de vista mais correto para conhecê-la, ou seja, o de alguém que nada tem a perder. $O$ proletariado teria por isso a vocação, como sujeito privilegiado da história, para instaurar a nova sociedade à altura do progresso técnico.

Quanto a essa tese, Lafargue parece ser inteiramente fiel à sua orientação marxista:

E não obstante, o proletariado, a grande classe que abrange a todos os produtores das nações civilizadas, a classe que, ao emancipar-se, emancipará a humanidade do trabalho servil e fará do animal humano um ser livre, o proletariado, traindo os seus instintos, esquecendo-se da sua missão histórica, deixou-se perverter pelo dogma do trabalho. Dura e terrível foi a sua punição. Todas as misérias individuais e sociais nasceram da sua paixão pelo trabalho (p. 23).

As fábricas modernas tornaram-se casas ideais de correção onde as massas operárias são encarceradas, onde se condenam a trabalhos forçados, durante doze e catorze horas, não só os homens, como também as mulheres e as crianças.

Tal é a lei inexorável da produção capitalista. Porque, por prestarem atenção às falaciosas palavras dos economistas, os proletários se entregaram de corpo e alma ao vício do trabalho, precipitam toda a sociedade numa dessas crises de superprodução que convulsionam o organismo social (p. 37).

A superprodução e a superabundância de mercadorias aviltam ainda mais o trabalho e a vida da classe trabalhadora no mundo capitalista, criando a crise que os mais fracos suportam, carregam sobre os ombros, e são os que sofrem mais:

Então, por haver superabundância de mercadorias e falta de compradores, as fábricas fecham as portas e a fome fustiga as populações operárias com o seu chicote de mil tiras (p. 37).

O pressuposto, ou melhor, a crença de que a salvação dos problemas da sociedade, como a miséria, a fome, a injustiça, só depende do crescimento econômico, ainda parece estar vivo hoje como ontem.

Os proletários, embrutecidos pelo dogma do trabalho, não compreendem que é o sobretrabalho que infligiram a si próprios durante o tempo da pretensa prosperidade a causa da sua miséria presente (p. 39).

No final do século XIX, no momento do auge da indústria e do progresso liderado pela burguesia, é a convicção dos operários, como hoje ainda é bastante generalizada a 
convicção de que com mais trabalho se resolvem os problemas de sobrevivência da população, do desejado bem-estar social, do desenvolvimento humano; quando apenas uma pequena atenção sem viseiras mostra a independência da riqueza com relação ao bem-estar da população; quando basta olhar sem preconceitos para ver que é preciso algo mais que a multiplicação dos produtos para garantir a dignidade dos produtores.

Em vez de aproveitar os momentos de crise para uma distribuição geral de produtos e uma manifestação universal de alegria, os operários, morrendo de fome, vão bater com a cabeça contra as portas da fábrica. Com rostos pálidos e macilentos, corpos emagrecidos, discursos lamentáveis, assediam os fabricantes: “(...) dêem-nos trabalho, não é a fome, mas a paixão do trabalho que nos atormenta!” (p. 39).

É assim caracterizada de modo dramático a irracionalidade do sistema, que poderia extirpar grande parte de seus males, não fosse a teimosia em não ver suas verdadeiras causas.

E esses miseráveis, que mal têm forças para se manter em pé, vendem doze a catorze horas de trabalho duas vezes mais barato do que quando tinham trabalho durante um certo período. E os filantropos da indústria continuam a aproveitar as crises de desemprego para fabricar mais barato (p. 39).

Mais surpreendente ainda é que não são apenas os empresários conscientes de suas intenções de lucro e acumulação; também não são apenas os outros coadjuvantes burgueses da cena capitalista que defendem a manutenção da intensidade de trabalho e produção, mas sim, são os próprios explorados que resistem em ver a causa de sua miséria.

E, no entanto, apesar da superprodução de mercadorias, apesar das falsificações industriais, os operários entulham o mercado, implorando: trabalho! trabalho! (p. 59).

Numa linguagem que associa a franqueza à ironia e aponta que a superprodução tem efeitos negativos também sobre a classe ociosa, Lafargue procede à crítica da ideologia do trabalho e das recomendações de economistas e moralistas modernos, mas aspira mais, quer justificar uma transformação de consciência e da valoração do trabalho e do ócio pelos operários.

Sabe que é tarefa árdua tentar convencer o proletariado de que a ideologia do trabalho, de que está imbuído, é perversa, porque o trabalho desenfreado que o domina no século dezenove é "o mais terrível flagelo que já atingiu a humanidade", e o trabalho só se tornará uma paixão útil à vida social quando for regulamentado e limitado a um máximo de três horas por dia.

Limitar-me-ei a demonstrar que, atendendo aos meios de produção modernos e à sua potência reprodutiva ilimitada, é preciso dominar a estranha paixão dos operários pelo trabalho e obrigá-los a consumir as mercadorias que produzem (p. 43).

O trabalho excessivo que vai colaborar para a superprodução, esta que, por sua vez, vai gerar a crise e despejar na rua multidões de trabalhadores, é claramente um vício, porque enfraquece e destitui o sujeito que o pratica.

Uma vez que o vício do trabalho está diabolicamente encravado no coração dos operários; uma vez que as suas exigências abafam todos os outros instintos da natureza; uma vez que a quantidade de trabalho exigida pela sociedade é forçosamente limitada pelo consumo e pela abundância de matéria-prima, por que razão devorar em seis meses o trabalho de todo o ano? (p. 59). 
A obsessão do trabalho é alimentada nos operários pelos discursos dos moralistas, dos economistas, dos sacerdotes. Em vez de reagirem contra a aberração mental que consiste em deixar-se escravizar pela atividade produtiva a ponto de não encontrar mais tempo para a contemplação e para as boas coisas da vida, que incluem a convivência afetuosa na família e na comunidade, e a prática da religião, "sacrossantificaram" o trabalho:

\begin{abstract}
Homens cegos e limitados, quiseram ser mais sábios do que o próprio Deus deles; homens fracos e desprezíveis, quiseram reabilitar aquilo que até mesmo o Deus deles amaldiçoara. Eu, que não professo o credo cristão, nem tenho posição econômica e moral como a deles, recuso-me a admitir as pregações dessa moral religiosa, econômica, livre-pensadora, considerando as terríveis conseqüências do trabalho na sociedade capitalista (p. 19).
\end{abstract}

Paul Lafargue refere-se à Grécia Antiga, quando trabalho e ócio recebiam a valorização contrária da tábua de valores moderna, sendo que os filósofos da Antigüidade ensinaram o desprezo pelo trabalho, considerado como degradação do homem livre, e cantavam o ócio como presente dos deuses, sobre isso não tendo discordâncias. "Os filósofos antigos discutiam entre si sobre a origem das idéias, mas eram unânimes quando se tratava de abominar o trabalho" (p. 81).

Lafargue refere uma especial resistência da valorização do ócio na cultura espanhola, o que não saberíamos dizer como se mantém em nosso tempo tão globalizado em seus valores e modos de vida, mas onde as diferenças culturais locais conseguem sobreviver: "Para os espanhóis, entre os quais o animal primitivo não está atrofiado, o trabalho é a pior das escravidões" (p. 21).

Contudo, apesar da constatação da insana obsessão pelo trabalho, generalizada nas classes espoliadas, Lafargue aponta perspectivas de emancipação por soluções revolucionárias; suas sugestões concretas vão no sentido da luta por menor jornada de trabalho à medida que a classe trabalhadora reconheça o seu poder e o imponha. Hoje, quando o número proporcional dos trabalhadores industriais se encontra reduzido, o poder da classe operária se vê substancialmente atingido, mas não desaparece.

Para forçar os capitalistas a aperfeiçoar as suas máquinas de madeira e de ferro, é preciso elevar os salários e diminuir as horas de trabalho das máquinas de carne e osso (p. 63).

A saída da armadilha em que as classes trabalhadoras foram presas, no trabalho alienado e aviltante, passa pela melhor utilização dos recursos que a tecnologia possibilita, pela integração do trabalho vivo humano com a potência produtiva das máquinas e, assim, pela diminuição drástica da jornada comum de trabalho.

Os proletários enfiaram na cabeça infligir aos capitalistas dez horas de forja e de refinaria; aí reside o grande erro, a causa dos antagonismos sociais e das guerras civis. Será necessário não impor o trabalho, mas proibi-lo (p. 69).

É requerida uma nova reforma da lei referente à jornada de trabalho, com drástica redução da jornada permitida. Oh, quão longe está a proposta de Lafargue dos esforços de produção máxima instaurados nas experiências socialistas realmente existentes no século XX! A sugestão mais ousada, com certeza utópica porque ainda não real, mas ainda assim possível, é aquela da jornada de três horas de trabalho para todos:

Se extirpando do seu coração o vício que a domina e avilta a sua natureza, a classe operária se erguesse com a sua força terrível, não para reclamar os Direitos do Homem, que não são senão os direitos da exploração capitalista, não para reclamar o Direito ao Trabalho, que não é senão o direito à miséria, mas para forjar uma lei de bronze que 
proibisse todos os homens de trabalhar mais de três horas por dia, a Terra, a velha Terra, tremendo de alegria, sentiria nela surgir um novo universo... Mas como pedir a um proletariado corrompido pela moral capitalista uma decisão viril? (pp. 76-77).

A proposta da jornada de três horas contida no manifesto de Lafargue, ainda hoje, longe de realizar-se mas materialmente possível, corresponde ao conceito blochiano de utopia concreta. Mas a dúvida continua: onde se encontram os grupos de operários que se autoreconheçam como essenciais ao sistema e por isso manteriam seu poder de convencimento, sua capacidade política de imposição de reformas, que tenham portanto a força para levar as situações na direção dessa nova diminuição da jornada de trabalho? Essa necessária potência política faz parte das capacitações que o trabalhador de hoje precisa adquirir através de sua educação, de sua formação individual e coletiva.

O discurso inflamado de Lafargue dirige-se diretamente aos operários de seu tempo e, para convencê-los, como já vimos, não hesita em reclamar o pensamento dos filósofos antigos:

escutem a linguagem destes filósofos, que estão sendo escondidos de vocês com cioso cuidado: um cidadão que dá o seu trabalho em troca de dinheiro degrada-se ao nível dos escravos, comete um crime que merece anos de prisão (p. 83).

E para acordar os trabalhadores do encantamento pelo esforço escravo, o autor não se resume a evocar filósofos antigos da tradição pagã greco-romana, não hesita em evocar a herança cultural e moral da Bíblia, especialmente a do Novo Testamento:

Cristo, em seu sermão na montanha, pregou a preguiça: "Contemplai o crescimento dos lírios dos campos; eles não trabalham nem fiam, e não obstante, digo-vos, Salomão, em toda a sua glória, não se vestiu com maior brilho" (p. 21).

Essa passagem evocada por Lafargue (Evangelho segundo São Mateus, VI, 28-29), onde o evangelho cristão ensina que a contemplação religiosa tem precedência sobre a atividade inquieta, é confirmada em outra, no Evangelho segundo São Lucas, quando Jesus se encontra em visita às irmãs Marta e Maria, e sua resposta à pergunta de Marta esclarece que Maria escolhera "a melhor parte":

Enquanto caminhavam, Jesus entrou num povoado, e certa mulher, de nome Marta, o recebeu em sua casa. Sua irmã, chamada Maria, sentou-se aos pés do Senhor, e ficou escutando a sua palavra. Marta estava ocupada com muitos afazeres. Aproximou-se e falou: "Senhor, não te importas que minha irmã me deixe sozinha com todo o serviço? Manda que ela venha ajudar-me!" O Senhor, porém, respondeu: "Marta, Marta! Tu te preocupas com muitas coisas; porém, uma só coisa é necessária, Maria escolheu a melhor parte, e esta não lhe será tirada" (Lucas, X, 38-42).

A "melhor parte", quer dizer, a parte da contemplação, da atenção prestada à palavra de Jesus, do ouvir atento, aquietado, dos ensinamentos do Senhor, da contemplação religiosa, onde se concentrou Maria, por oposição à inquietação e atividade com os trabalhos domésticos, em que se ocupa Marta.

Essa concentrada quietude a ouvir a palavra é uma das dimensões abertas pela vida menos agitada, do ócio em seu sentido mais elevado - pode-se dizer assim, de atividade espiritual ou da contemplação, seja teórica ou teorética, que é impedida pela insana obsessão moderna do trabalho como por toda agitação. 


\section{Convite à revalorização da skholé}

$\mathrm{Na}$ direção aberta pelas provocações de $\mathrm{O}$ direito à preguiça, situando-as nas condições de nosso tempo - de alto desenvolvimento da tecnologia e, ao mesmo tempo, diminuição, ou mesmo, em certas áreas, desaparecimento do emprego na indústria, na era da automação da produção e das comunicações, da cibernética e da robótica, que parecem confirmar as intuições de Lafargue -, somos convidados a reconsiderar as possibilidades que se abrem à sociedade tecnológica, tomando a sério, como horizonte, uma inversão da divisão do tempo de trabalho e do "tempo livre", das novas formas de dar sentido à vida, de outro modo que pela solução moderna do trabalho como na sociedade industrial.

Por tudo isso, somos levados a sugerir que se pense sobre uma revalorização da skholè - palavra grega que quer dizer ócio e está na origem da palavra "escola”.

Atualmente, a ausência de trabalho não é vivenciada como possibilidade positiva de reflexão, recriação, estudo. O ócio, que pode ser criativo e possibilitar a dedicação às atividades do espírito, consideradas pelos filósofos como as mais próprias do ser humano porque correspondem àquilo que faz a sua diferença com relação aos outros seres, é alvo de desaprovação e fonte de inquietude.

A diminuição do trabalho hoje, depois de vários séculos de doutrinação para a religião do trabalho, é sentida quase exclusivamente em seus aspectos negativos, como vulnerabilidade, dependência e insegurança, como desvantagem no plano do consumo e exclusão.

A automação na indústria e a globalização terminam rapidamente com os empregos que se abriram com a industrialização, que ainda há pouco continuavam a abrir-se nos países de industrialização recente. O trágico desse processo de corte do emprego na indústria, do ponto de vista humano, é que se continua colocando o emprego estável como meta geral nas vidas pessoais.

Sendo assim, os que não podem ser integrados no novo mercado de trabalho, reduzido, "enxugado", são excluídos do reconhecimento social, do respeito social como da capacidade de sobrevivência independente e, conseqüentemente, do respeito por si mesmos. É assim que se instala, para usar a expressão de Viviane Forrester (1997), o "horror econômico".

$\mathrm{Na}$ atual mutação das realidades econômicas nas sociedades pós-industriais, transformou-se a equação entre tempo de trabalho e tempo de lazer, entre ócio e atividade. A transformação tem se realizado de modo imprevisto, portanto, assusta e desperta desconfiança, quando não é mesmo explorada no sentido de alienação ainda maior.

Todavia, com maior consciência social e outras atitudes políticas, haveria a possibilidade de todos trabalharem menos podendo fazer melhor uso do tempo liberto da atividade produtiva, servindo-se assim à educação, à cultura, à felicidade coletiva e ao desenvolvimento humano.

Os planejadores e analistas de economia, bem como os políticos, parecem continuar negando-se a constatar a transformação inevitável. Os discursos continuam a batalhar por mais emprego, sem que se percebam exatamente quais as finalidades de tal esforço, nem que se façam reconhecer as dimensões da mudança. Na evolução atual do mundo do trabalho, no entanto, algo parece não poder mais ser recuperado, a indústria não retrocederá dos avanços tecnológicos e a maioria das pessoas terá de encontrar seu modo de inserção na vida comunitária, para o seu reconhecimento e sobrevivência, através de outros serviços, nãoindustriais. 
O trabalho material e os serviços também sentem a influência das novas tecnologias, sendo preciso cada vez mais desenvolver-se em atividades da ordem das relações interpessoais, do cuidado social e pessoal, que incluem a dimensão do afetivo, do chamado "trabalho imaterial". Segundo Hardt e Negri (2004), são três os tipos de trabalho que impulsionam a pós-modernização da economia global:

A atividade fabril é vista como serviço, e o trabalho material da produção de bens duráveis mistura-se com o trabalho imaterial e se inclina na direção dele. O segundo é o trabalho de tarefas analíticas e simbólicas, que se divide na manipulação inteligente e criativa de um lado e nos trabalhos simbólicos de rotina do outro. Finalmente, a terceira espécie de trabalho imaterial envolve a produção e a manipulação de afetos e requer contato humano (virtual ou real), bem como trabalho do tipo físico (p. 314).

Está posto nas atuais circunstâncias, pois, um grande desafio aos humanistas, educadores, orientadores da opinião, aos que lideram o avanço do conhecimento, também no domínio das ciências humanas. A todos eles, ou melhor, a todos nós é exigido rever a ética do trabalho, repensar a ideologia da inserção social dos cidadãos enquanto trabalhadores para resgatar o valor e o sentido de outras dimensões do viver humano e do viver em comum.

Só uma reconsideração corajosa e paciente dos diversos aspectos da situação, com um olhar sem preconceitos, sem teimar no ponto de vista das situações que desaparecem, deverá possibilitar que se encontrem novos rumos e formas positivas de enfrentar a mudança e, assim, consigamos evitar que as novas gerações sem "pleno emprego" venham a sentir-se menos humanas ou bem-sucedidas, porque sem participação ou reconhecimento, problema psicossocial que pode também alimentar a violência dentro das sociedades.

Os mais comuns retratos da situação partem da constatação do que está faltando, do emprego que falta e do novo desemprego que se acentua, como se a perda fosse ao mesmo tempo inevitável e terrível, porque de fato é uma mudança muito importante e desafiante, e como se não houvesse nenhum lado positivo a ser registrado ou a considerar-se pelo menos como esperança, na perspectiva do futuro.

Como todos lamentam o desaparecimento do emprego! Não teria sido assim também quando o trabalho evoluiu da servidão feudal para o emprego assalariado no capitalismo industrial? Não terá sido também assim quando, pela abolição da escravidão no Brasil, os negros foram lançados na estrada e se negaram aos empregos na recente indústria?

Segundo Forrester (1997), as análises falam em crise do emprego, em crises do trabalho, quando seria mais adequado e verdadeiro falar em mutação e não apenas mutação de uma sociedade, mas de uma civilização. Os contemporâneos participam de uma nova era, mas nem conseguem observá-la, nem admitem nem percebem que a era anterior desapareceu.

Nossos conceitos de trabalho e, por conseguinte, de desemprego, em torno dos quais a política atua (ou pretende atuar), tornaram-se ilusórios e nossas lutas em torno deles, tão alucinadas quanto as do Quixote contra os moinhos (p. 7).

Estamos vendo uma realidade transformada sendo compreendida de modo falso por expectativas e categorias do período passado, sem que se consiga dar o passo para a compreensão e a boa relação dinâmica com a situação real, por sobrevivência dos conceitos válidos para a época anterior.

O sentido de "desemprego" é hoje inteiramente outro, mesmo em sociedades do chamado primeiro mundo. Não se trata mais de um período transitório que o operário atravessa, entre uma situação de emprego e outra, mas de uma mutação de caráter global, societário, em que os empregos não existem mais na mesma quantidade na área da produção material. 
Parece evidente que, em defesa da saúde física e mental das populações jovens, é preciso proceder-se a uma revisão de valores e a uma reflexão coletiva sobre a ética que predomina, para suspender o juízo e pelo menos não marginalizar socialmente os que a economia marginalizou ou determinou à dependência.

\section{Ócio e pensamento}

Evidentemente, o manifesto de Lafargue tem um claro sentido prático dentro da luta política operária e não se trata em primeiro lugar de um elogio ao ócio em defesa da filosofia; todavia, esse é um aspecto que eu gostaria lhe fosse acrescentado.

A ligação do ócio com a filosofia e o cultivo do pensamento a partir do espanto admirativo parecem lugar-comum, quase um preconceito que tomou forma de provérbio, embora em círculos restritos: do ócio nasce o filosofar.

Essa ligação do ócio com a reflexão, contudo, em nosso tempo anda bastante esquecida; e quem em nossa época teve a coragem de fazer efetivamente o elogio do ócio, como Bertrand Russell, com certeza prezando a filosofia, não aspirou a convencer multidões.

Porém, diante da persistência da ética de trabalho burguesa, confrontada à realidade do novo desemprego, parece evidente que é preciso proceder-se a uma revisão de valores.

Para que pudéssemos, a exemplo dos filósofos antigos e medievais, voltar a ter apreço pela não-atividade em boa consciência e para a recebermos como um dom que nos é possibilitado no bojo ou no avesso do progresso tecnológico, torna-se necessária uma inversão no plano dos "valores" modernos, uma verdadeira revolução ética ou "transvaloração", conforme linguagem mais ao gosto da moda filosófica.

A crítica do trabalho e a proposta de revalorização do ócio significaria uma revolução tão grande quanto o foi a inversa, da transformação do trabalho em valor moral e religioso, ocorrida não se sabe precisar exatamente em que momento da passagem para a idade moderna, possivelmente em combinação com a crítica do catolicismo na ótica da reforma protestante.

Para que essa transvaloração possa ocorrer e, não é demais lembrarmos, ela só poderia ocorrer de modo "parcelar" e em movimento, em contínua modificação, é imensa a tarefa de todos os que se ocupam com a educação e a orientação das pessoas neste mundo em transformação, sobretudo das crianças, dos adolescentes, dos jovens, mas também dos adultos e ainda dos mais idosos.

O "horror econômico", a armadilha do desaparecimento do emprego na indústria quando recém a escola começa a valorizar a profissionalização, exige uma nova educação e educação moral. A educação nas atuais circunstâncias não é tarefa simples, pois não pode continuar a ser o que foi na tradição nem pode transformar-se no que pretendia tornar-se ainda há pouco, como escola ativa e educação para o trabalho na produção material.

Enquanto Lafargue detectava que, para poder estabelecerem-se as três horas de trabalho para todos, tinha-se o problema educacional de educar a burguesia para o trabalho e a sabedoria, educando para o ócio e o consumo o proletariado doente de supertrabalho e abstinência, hoje em dia o problema se coloca, na compreensão de De Masi (2001), de modo um tanto diferente: embora a globalização tenda a uniformizar os modos de vida pelo planeta, em nosso tempo trata-se de reeducar a população de alta renda nos países ricos para viver bem e redescobrir as virtudes do ócio, enquanto em algumas regiões do planeta é ainda necessário educar a massa de pobres para aprender a trabalhar (p. 33). 
Descobrir as virtudes do ócio exige também entender em que o ócio pode servir à humanização. Essa é uma perspectiva de pesquisa que devemos desenvolver com empenho, revisando com atenção e cuidado o conceito de humano, humanidade, humanização, que as novas situações tão mudadas chegam a colocar em dúvida.

A propósito do que pode servir à humanização um tempo que exceda a atividade de produção, vale retornar à interpretação de Hannah Arendt (1981), em sua apresentação (p. 23) do conceito de vita contemplativa por oposição ao de vita activa, tais como tiveram vigência na cultura e na história ocidental, incluindo a consideração da história da filosofia e a do pensamento religioso.

A apresentação de Arendt dá-nos o que pensar também sobre os desafios que estão postos em nosso tempo para as pessoas que desejam colaborar para minorar o sofrimento causado pela atual mutação na civilização industrial.

De modo inspirado e cuidadoso, Arendt apresenta a sua maneira de ver a evolução da escala de valores dividida entre ação e contemplação, da Grécia homérica à platônica, depois, de Aristóteles a Agostinho, que atravessou o período medieval até a sua modificação nos tempos modernos; e acentua, na concepção grega, o caráter de ação política da vida ativa, contraposta ao ócio da vida contemplativa, portanto, Arendt acentua a contraposição entre a filosofia e a política.

A expressão vita activa, compreendendo todas as atividades humanas e definida do ponto de vista da absoluta quietude da contemplação, corresponde, portanto, mais à askholia grega ("ocupação", "desassossego") com a qual Aristóteles designava toda atividade, que ao bios politikos dos gregos (Arendt, 1981, p. 23).

A propósito, a autora esclarece em nota de rodapé na mesma passagem:

A palavra grega skholè, como a latina otium, significa basicamente isenção de atividade política e não simplesmente lazer, embora ambas sejam também usadas para indicar isenção do labor e das necessidades da vida. De qualquer modo, indicam sempre uma condição de isenção de preocupações e cuidados (p. 23).

Apesar de nos posicionarmos de maneira positiva ante a vita contemplativa, que inclui a atividade teorética, a concentração na ciência pura e na arte (o lúdico, o jogo, a festa e a criação artística), convém não deixar de perceber que em nosso tempo tudo tende a se transformar em "neg-ócio" e a mais pura das artes pode ser submetida às regras de mercado e à lógica comercial. E assim, o que é contrário de tal forma se assemelha que pode ser visto também o ócio como "neg-ócio", contrariando o sentido das nossas observações.

Para terminar esta breve e provisória apresentação do sonho de Lafargue de uma sociedade de operários que superem a obsessão do trabalho alienado e se dêem o direito ao descanso e ao ócio prazeroso, cabe ainda dizer pelo menos algumas poucas frases que indiquem o lugar de onde falamos. Cabe exercitar pelo menos brevemente um olhar brasileiro sobre a questão da diminuição do trabalho e do aumento material do tempo livre prometidos pelas análises dos sociólogos contemporâneos da economia do trabalho e do ócio.

Temos no horizonte uma promessa de civilização que se parece menos com a utopia da modernidade, do trabalho planejado nos detalhes, tanto no estilo da ilha fantástica de Thomas More, como no do falanstério libertário de Charles Fourier, repletos de atividade produtiva; muito embora, em ambos, as jornadas devessem ser reduzidas porque melhor distribuídas - em More, por meio de renúncia e disciplina e, em Fourier, por meio do respeito às paixões e ao prazer.

Um olhar brasileiro nos leva a ver com compreensão particular o lado positivo da diminuição e do anunciado desaparecimento do emprego na indústria. Se fomos pegos na 
armadilha da desesperança e da angústia pela diminuição do trabalho é porque, de um lado, não enfrentamos como devíamos ainda a questão da distribuição, tanto das riquezas como também do próprio trabalho necessário; de outro, é porque nos deixamos contagiar com a mentalidade do trabalho própria da época industrial, do sistema capitalista, ligados à ideologia do cristianismo ascético da ética puritana, que nos foi transmitido no bojo do american way of life, que recebemos pela invasão cultural do cinema e das influências dos meios de comunicação em massa.

$\mathrm{Na}$ terra do carnaval, do futebol, de todos os esportes que cativam as multidões e conquistam também aquelas dos outros países centrais como se foram tão importantes quanto as grandes causas dos tempos modernos; na terra da música cadenciada e das telenovelas que se fazem cantar e contar em todas as línguas por todos os quadrantes da Terra, não deveria assustar o aviso do fim dos empregos nas indústrias de bens materiais.

Não deveríamos nos assustar demais com esse aviso porque há entre nós talento e prazer em transformar em trabalho as artes da festa e do lazer; porque encontramos mesmo nelas meios de subsistência; assim como também, em nosso país mais que em outros, parece haver menos preconceito e inquietude por deixar invadir nossas vidas pelo tempo não controlado da liberdade, do descanso, do ócio, que é abertura para a diversão e também para a filosofia.

Nosso lado Macunaíma é real. Façamos dele virtude, força para inventar o novo e o melhor; chance de encontrar um modo de vida mais humano e mais justo, que nos devemos, para superar as obsessões aviltantes, como a "religião do trabalho" marcada pela hipocrisia porque alimentada pela exploração, pelo sangue dos outros.

\section{Referências}

Albornoz, S. G. (1999). O enigma da esperança: Ernst Bloch e as margens da história do espirito. Petrópolis: Vozes.

Albornoz, S. G. (2002). Violência ou não-violência: um estudo em torno de Ernst Bloch. Santa Cruz do Sul: Edunisc.

Albornoz, S. G. (2003). Trabalho e utopia na modernidade. Cadernos de Psicologia Social do Trabalho, 6, 1-13.

Albornoz, S. G. (2005). Trabalho e utopia na modernidade II: o trabalho na Cidade do Sol de Tommaso Campanella. Cadernos de Psicologia Social do Trabalho, 8, 59-69.

Albornoz, S. G. (2006a). Educação e trabalho nas Considerações sobre o governo da Polônia. Cadernos de Psicologia Social do Trabalho, 9 (2), 73-87.

Albornoz, S. G. (2006b). Ética e utopia: ensaio sobre Ernst Bloch. Porto Alegre: Movimento.

Albornoz, S. G. (2007). Atração passional, trabalho e educação em O novo mundo industrial e societário de Charles Fourier. Cadernos de Psicologia Social do Trabalho, 10 (1), 1-19.

Arendt, H. (1981). A condição humana. Rio de Janeiro: Forense Universitária.

Bloch, E. (2006). O princípio esperança (vol. I, II e III). Rio de Janeiro: Contraponto.

Chaui, M. (2000). Introdução. In P. Lafargue, O direito à preguiça (pp. 9-56). São Paulo: Hucitec.

De Masi, D. (Org.) (2001). A economia do ócio. Rio de Janeiro: Sextante.

Engels, F. (1988). Do socialismo utópico ao socialismo científico. São Paulo: Global.

Forrester, V. (1997). O horror econômico. São Paulo: Unesp. 
Hardman, F. F. (1980). Introdução: trabalho e lazer no movimento operário (pp. 13-20). In P. Lafargue, O direito à preguiça. A religião do capital. São Paulo: Kairós.

Lafargue, P. (1909). Le déterminisme économique de Karl Marx, recherche sur l'origine de l'évolution des idées de justice, du bien, de l'âme et de Dieu. Paris: Giard et Brière.

Lafargue, P. (2005). Le droit à la paresse. Paris: Allia. (Originalmente publicado em 1880)

Lafargue, P. (1983). O direito à preguiça. A religião do capital. São Paulo: Kairós.

Lafargue, P. (1999). O direito à preguiça (J. Teixeira Coelho Netto, trad.). São Paulo: Hucitec.

Lafargue, P. (2001). O direito ao ócio (Carlos Irineu W. da Costa, trad.). In D. De Masi (Org.), A economia do ócio (pp. 139-183). Rio de Janeiro: Sextante.

Lafargue, P. (2003) O direito à preguiça (ed. bilíngüe). (Otto Lamy de Correa, trad). São Paulo: Claridade.

Matos, O. (2003). A dignidade da preguiça, a dignidade humana. Prefácio. In P. Lafargue, O direito à preguiça (pp. 7-13). São Paulo: Claridade.

Negri, A. \& Hardt, M. (2004). Império. Record: Rio de Janeiro.

Russell, B. (2001). O elogio ao ócio. In D. De Masi (Org.), A economia do ócio (pp. 47-137). Rio de Janeiro: Sextante.

Vigil, C. (1959). El Erial. Buenos Aires: Atlântica.

Weber, M. (2004). A ética protestante e o espírito do capitalismo. São Paulo: Companhia das Letras.

\section{Endereço para correspondência}

suzanaalb@viavale.com.br

Recebido em: 25/04/2007

Aprovado em: 25/05/2008 